\title{
Advancing Sequential Managed Aquifer Recharge Technology (SMART) Using Different Intermediate Oxidation Processes
}

\author{
Karin Hellauer ${ }^{1}$, Dorothea Mergel ${ }^{2}$, Aki S. Ruhl ${ }^{2}$, Josefine Filter ${ }^{2}$, Uwe Hübner ${ }^{1, *}$, \\ Martin Jekel ${ }^{2}$ and Jörg E. Drewes ${ }^{1}$ \\ 1 Chair of Urban Water Systems Engineering, Technical University of Munich, Am Coulombwall 3, \\ 85748 Garching, Germany; karin.hellauer@tum.de (K.H.); jdrewes@tum.de (J.E.D.) \\ 2 Chair of Water Quality Control, Technische Universität Berlin, Straße des 17. Juni 135, 10623 Berlin, \\ Germany; doro.mergel@t-online.de (D.M.); aki.s.ruhl@tu-berlin.de (A.S.R.); \\ josefine.filter@campus.tu-berlin.de (J.F.); martin.jekel@tu-berlin.de (M.J.) \\ * Correspondence: u.huebner@tum.de; Tel.: +49-89-2891-3706
}

Academic Editors: Pieter J. Stuyfzand and Niels Hartog

Received: 3 February 2017; Accepted: 13 March 2017; Published: 17 March 2017

\begin{abstract}
Managed aquifer recharge (MAR) systems are an efficient barrier for many contaminants. The biotransformation of trace organic chemicals (TOrCs) strongly depends on the redox conditions as well as on the dissolved organic carbon availability. Oxic and oligotrophic conditions are favored for enhanced TOrCs removal which is obtained by combining two filtration systems with an intermediate aeration step. In this study, four parallel laboratory-scale soil column experiments using different intermittent aeration techniques were selected to further optimize TOrCs transformation during MAR: no aeration, aeration with air, pure oxygen and ozone. Rapid oxygen consumption, nitrate reduction and dissolution of manganese confirmed anoxic conditions within the first filtration step, mimicking traditional bank filtration. Aeration with air led to suboxic conditions, whereas oxidation by pure oxygen and ozone led to fully oxic conditions throughout the second system. The sequential system resulted in an equal or better transformation of most TOrCs compared to the single step bank filtration system. Despite the fast oxygen consumption, acesulfame, iopromide, iomeprol and valsartan were degraded within the first infiltration step. The compounds benzotriazole, diclofenac, 4-Formylaminoantipyrine, gabapentin, metoprolol, valsartan acid and venlafaxine revealed a significantly enhanced removal in the systems with intermittent oxidation compared to the conventional treatment without aeration. Further improvement of benzotriazole and gabapentin removal by using pure oxygen confirmed potential oxygen limitation in the second column after aeration with air. Ozonation resulted in an enhanced removal of persistent compounds (i.e., carbamazepine, candesartan, olmesartan) and further increased the attenuation of gabapentin, methylbenzotriazole, benzotriazole, and venlafaxine. Diatrizoic acid revealed little degradation in an ozone-MAR hybrid system.
\end{abstract}

Keywords: dissolved organic carbon; managed aquifer recharge; redox conditions; trace organic chemicals

\section{Introduction}

The potential to cause adverse health effects by the presence of trace organic chemicals (TOrCs), such as pharmaceuticals, household chemicals, industrial chemicals, and pesticides, in the aqueous environment is increasingly recognized as a serious environmental issue [1-4]. Due to their insufficient degradation in conventional wastewater treatment plants, TOrCs can be detected in surface water, 
groundwater and drinking water in a concentration range of $\mathrm{ng} / \mathrm{L}$ to $\mu \mathrm{g} / \mathrm{L}[3,5-8]$. Managed aquifer recharge (MAR) systems, such as riverbank filtration (RBF), soil aquifer treatment (SAT), or aquifer recharge and recovery (ARR) efficiently remove microbial contaminants, organic matter and TOrCs by adsorption, physicochemical filtration processes, as well as biological transformation while combining the advantages of low energy demand, little chemical input, and no generation of waste streams [9-12]. For a majority of TOrCs, biotransformation is the dominant removal mechanism [13]. Previous studies have revealed that degradation of TOrC is more favorable under oxic and carbon depleted conditions represented by a low biodegradable dissolved organic carbon (BDOC) content [14-19]. The coupling of two MAR systems with an intermediate aeration step, as established by the sequential managed aquifer recharge technology (SMART) [20], was designed to provide these favorable conditions in the second infiltration system. In the first infiltration step of SMART (mimicking conventional riverbank filtration systems), easily biodegradable DOC is quickly consumed, usually resulting in complete oxygen depletion and prevailing anoxic conditions. After re-aeration of the extracted water, carbon-depleted and oxic conditions can be maintained in the subsequent subsurface filtration system. This approach was successfully demonstrated at the full-scale MAR facility Prairie Waters Project (Aurora, CO, USA) showing enhanced biodegradation of various TOrCs (e.g., caffeine, diclofenac, dilantin, gemfibrozil, meprobamate, and naproxen) compared to single-stage conventional riverbank filtration [20].

However, some TOrCs such as the antiepileptic drugs carbamazepine and primidone are highly persistent to biodegradation under most conditions. For the removal of such compounds during SMART, an additional barrier would be needed. Ozonation is a well-established process for the removal of many TOrCs [21,22]. Since it provides additional dissolved oxygen and simultaneously increases the BDOC content, it was proposed as a suitable method in combination with subsequent groundwater infiltration [23-25].

The aim of this study was to validate the SMART concept in a laboratory-scale soil column set-up fed with a blend of wastewater treatment plant effluent and Lake Tegel water. Furthermore, the removal of persistent TOrCs during SMART was enhanced by replacing aeration with oxidation by ozone. Therefore, four parallel soil column set-ups were established, each consisting of two columns and subject to different intermediate oxidation techniques: no aeration (reference system), aeration with air, aeration with oxygen, and aeration with ozone.

\section{Materials and Methods}

\subsection{Soil Column Experiments}

The laboratory-scale soil column experiment consisted of four parallel systems. Each system was comprised of two columns ( $h=1.00 \mathrm{~m}$; ID $=0.14 \mathrm{~m}$; sampling ports: $0.25,0.50,0.75 \mathrm{~m})$, which were connected in series (Figure 1). The intermediate treatment differed by applying different oxidation techniques: no aeration (system BF), aeration with air (SMART air), aeration with pure oxygen (SMART $\mathrm{O}_{2}$ ), or aeration/oxidation with ozone $\left(0.6 \pm 0.1 \mathrm{mg} \mathrm{O}_{3} / \mathrm{mg} \text { DOC, } n=12 \text {; SMART O}\right)_{3}$ ). The columns were filled with sand which derived from recharge basin No. 3 at the full-scale Saatwinkel MAR facility, Berlin. Sand for the first column of all systems was taken from 0 to $100 \mathrm{~cm}$ depth. For the subsequent columns, the top $20 \mathrm{~cm}$ colmation layer was removed. The sand was sieved and homogenized to remove any constituents larger than $4 \mathrm{~mm}$. After preconditioning for 10 months (40 days with tap water, 9 months with Lake Tegel water), experiments were conducted for five months with a mixture of Lake Tegel water and effluent from wastewater treatment plant (WWTP) Ruhleben in a ratio of 3:1 to simulate the worst case scenario for the influence of WWTP effluent. Lake water and secondary effluent were collected monthly and stored at room temperature (lake water) or at $11^{\circ} \mathrm{C}$ (secondary effluent), respectively. The feed container was refilled weekly and stored at room temperature. The columns were operated top-down with a flow rate of $60 \mathrm{~mL} / \mathrm{h}$ resulting in a hydraulic retention time (HRT) of approximately six days (based on preliminary experiments with the same column set-up). The influent was delivered using an 8-channel Ismatec pump (model 931, 
Ismatec, Wertheim, Germany) and Pharmed ${ }^{\circledR}$ Ismaprene tubings (Ismatec Tubing, Persistaltic, 2-Stop, Color: Purple/White; Kinesis, Langenfeld, Germany).

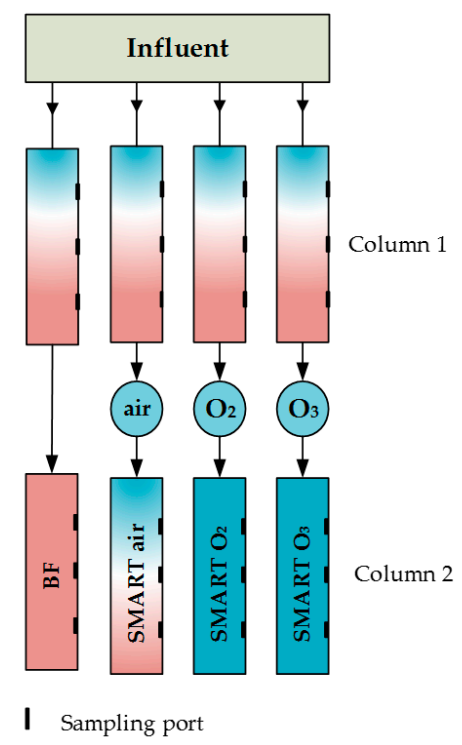

Figure 1. Conceptual design of the laboratory-scale soil column set-up $(\mathrm{h}=1.00 \mathrm{~m}, \mathrm{ID}=0.14 \mathrm{~m}$; HRT $\approx 6$ days).

\subsection{Aeration/Oxidation}

Intermediate aeration of the SMART air system was achieved using an air stone diffuser in a small bubble column. Aerated water was delivered to the second column by gravity. Treatment with pure oxygen and ozone was conducted weekly in a $13 \mathrm{~L}$-semi-batch stirred tank reactor. Gaseous ozone was produced from pure oxygen using a Modular 8 HC generator (Wedeco, Herford, Germany). Ozone concentrations of applied and off-gas as well as gas flow rate were measured continuously using BMT 964 and BMT 961 TPC (BMT, Stahnsdorf, Germany) and 807 MFM O2 (Bürkert, Ingelfingen, Germany) probes, respectively. In order to set up a complete mass balance and calculate consumed ozone, all off-gas ozone was stripped with pure oxygen before sampling. For aeration with pure oxygen, the system was used without ozone production for ten minutes. The oxygen- or ozone-treated water was fed to the second columns from Plastigas ${ }^{\circledR}$ bags (Linde, Pullach, Germany) to prevent degassing with a slightly reduced flow rate of $58 \mathrm{~mL} / \mathrm{h}$.

\subsection{Analytical Methods}

The samples from the in- and effluents of each column, as well as after the aeration with pure oxygen or the oxidation with ozone, respectively, were collected once a week with respect to the HRT. Additionally, in the second columns of the systems SMART air, SMART $\mathrm{O}_{2}$ and SMART $\mathrm{O}_{3}$, depth profile measurements were performed for the parameters dissolved oxygen, dissolved organic carbon (DOC), ultraviolet absorbance at $254 \mathrm{~nm}\left(\mathrm{UV}_{254}\right)$, and TOrCs every second to third week. The dissolved oxygen was measured in situ by use of oxygen flow through cells (PreSens, Regensburg, Germany). All samples were filtered (cellulose nitrate, $0.45 \mu \mathrm{m}$; Sartorius, Göttingen, Germany) prior to all analyses except for iron and manganese, which were measured unfiltered. The nitrate, nitrite, and ammonia concentrations were determined using a flow injection analysis (FIASTAR 5000, Foss Tecator, Hamburg, Germany). Iron and manganese measurements were carried out using atom absorption spectrometry (Flame: 906AA, GBC-Scientific Equipment Pty Ltd., Hampshire, IL, USA; Graphit furnace: SpectrAA-400, Varian, Palo Alto, CA, USA). The DOC concentration was determined by a varioTOC Cube analyzer (Elementar, Langenselbold, Germany) and the $\mathrm{UV}_{254}$ was measured on a spectral photometer Lamda 12 (Perkin Elmer, Waltham, MA, USA). The specific UV absorbance 
(SUVA) was calculated as the ratio of the $\mathrm{UV}_{254}$ and the DOC concentration. The quantification of selected TOrCs was conducted by high performance liquid chromatography coupled with tandem mass spectrometry (HPLC-MS/MS) based on the method described by Zietzschmann et al. [26]. The compounds were chromatographically separated with a XSelect HSS T3 XP column $(2.1 \mathrm{~mm}$ inner diameter, $50 \mathrm{~mm}$ length, $2.5 \mu \mathrm{m}$ spherical silica particles as substrate, C18 phase, reversed-phase mode) that was protected with an XSelect HSS T3 VanGuard pre-column (2.1 mm inner diameter, $5 \mathrm{~mm}$ length, $2.5 \mu \mathrm{m}$ particle size) and detected on a triple quadrupole with electro spray ionization (TSQ Vantage; Thermo Scientific, Waltham, MA, USA). Ultra-pure water mixed with 5 vol.- $\%$ methanol and 0.1 vol.- $\%$ formic acid and pure methanol were used as mobile phases at a volume flow of $500 \mu \mathrm{L} / \mathrm{min}$ using a linear gradient. All TOrCs, their limits of quantification (LOQ), fragments for quantification/qualification as well as internal standards used for quantification are listed in Table S1.

\section{Results and Discussion}

\subsection{Redox Conditions}

Relevant redox parameters in all systems are summarized in Table 1. The results of the first filtration step are given as mean value of all four columns. The oxygen concentration in the influent with $7.7 \pm 0.4 \mathrm{mg} / \mathrm{L}$ was almost saturated and completely consumed within the first 1.5 days of infiltration (Table 1, Figure 2a). Significant nitrate reduction (students $t$-test, paired, $\alpha<0.05$ ), formation of nitrite, and dissolution of manganese from the soil confirm anoxic conditions in the first columns. These results are in line with previous research reporting mostly anoxic bank filtration conditions in Berlin with rapid oxygen consumption by a high content of organic material [27]. The dissolution of manganese within the first filtration step slightly decreased during the experimental period, which may be explained by the decreasing availability of particulate organic carbon (POC) from the sand. The iron concentrations in the entire soil column system were not higher than $0.4 \mathrm{mg} / \mathrm{L}$. In the second column of the reference system without aeration, an additional decrease of nitrate concentrations indicated prevailing anoxic conditions. Manganese was slightly removed, possibly due to oxygen intrusion resulting in Mn(II) oxidation and precipitation between the columns. After aeration with air, dissolved oxygen was quickly consumed again in the second column (Figure $2 b$ ). Subsequent column passage in this column can be described as suboxic, which is characterized by a dissolved oxygen concentration of less than $1.0 \mathrm{mg} / \mathrm{L}$, but no significant consumption of alternative electron acceptors [28]. Only aeration with pure oxygen and treatment by ozone, both leading to high oversaturation of dissolved oxygen, resulted in fully oxic conditions throughout the second columns (Table 1). In all intermediate aeration/oxidation processes, manganese (II) was oxidized and deposited on the top of the columns as a dark layer, which was removed manually every three to four months. $\mathrm{NH}_{4}{ }^{+}-\mathrm{N}$ concentrations were not higher than $0.03 \pm 0.02 \mathrm{mg} / \mathrm{L}$ in all systems $(n \geq 14)$.

Table 1. Dissolved organic carbon (DOC) concentration and redox parameters measured in the system influents and effluents as well as after the aeration with air, pure oxygen or ozone respectively.

\begin{tabular}{|c|c|c|c|c|c|c|c|c|}
\hline \multirow{2}{*}{ Para-Meter } & \multirow{2}{*}{$\begin{array}{l}\text { Influent } \\
n \geq 17\end{array}$} & \multirow{2}{*}{$\begin{array}{c}\text { Column } 1 \\
n \geq 64\end{array}$} & \multicolumn{2}{|c|}{ After Aeration $n \geq 16$} & \multirow{2}{*}{$\begin{array}{c}\text { BF } \\
n \geq 15\end{array}$} & \multirow{2}{*}{$\begin{array}{c}\text { Smart Air } \\
n \geq 15\end{array}$} & \multirow{2}{*}{$\begin{array}{c}\text { Smart } \mathrm{O}_{2} \\
n \geq 14\end{array}$} & \multirow{2}{*}{$\begin{array}{c}\text { Smart } \mathrm{O}_{3} \\
n \geq 15\end{array}$} \\
\hline & & & Air & $\mathrm{O}_{2}$ and $\mathrm{O}_{3}$ & & & & \\
\hline DOC (mg/L) & $8.2 \pm 0.6$ & $6.6 \pm 0.7$ & - & $6.3 \pm 0.5^{*}$ & $6.5 \pm 0.6$ & $5.8 \pm 0.4$ & $5.2 \pm 0.5$ & $4.4 \pm 0.4$ \\
\hline $\mathbf{O}_{2}(\mathrm{mg} / \mathrm{L})$ & $7.74 \pm 0.43$ & $0.02 \pm 0.09$ & $7.14 \pm 0.45$ & $22.01 \pm 5.76$ & $0.03 \pm 0.08$ & $0.04 \pm 0.10$ & $14.32 \pm 4.50$ & $16.12 \pm 2.08$ \\
\hline $\mathbf{N O}_{3}-\mathbf{N}(\mathrm{mg} / \mathrm{L})$ & $4.8 \pm 0.8$ & $3.8 \pm 0.7$ & - & $3.8 \pm 0.7$ & $3.5 \pm 0.8$ & $3.7 \pm 0.7$ & $3.9 \pm 0.6$ & $4.0 \pm 0.7$ \\
\hline $\mathbf{N O}_{2}-\mathbf{N}(\mathrm{mg} / \mathrm{L})$ & $0.0 \pm 0.0$ & $0.3 \pm 0.1$ & - & $0.0 \pm 0.0$ & $0.2 \pm 0.0$ & $0.0 \pm 0.0$ & $0.0 \pm 0.0$ & $0.0 \pm 0.0$ \\
\hline $\mathbf{F e}(\mathrm{mg} / \mathrm{L})$ & $0.2 \pm 0.1$ & $0.1 \pm 0.1$ & - & - & $0.1 \pm 0.1$ & $0.1 \pm 0.1$ & $0.1 \pm 0.1$ & $0.1 \pm 0.1$ \\
\hline $\operatorname{Mn}(\mathrm{mg} / \mathrm{L})$ & $0.1 \pm 0.1$ & $1.1 \pm 0.4$ & - & - & $0.6 \pm 0.2$ & $0.1 \pm 0.1$ & $0.0 \pm 0.0$ & $0.0 \pm 0.0$ \\
\hline \multicolumn{2}{|c|}{$\begin{array}{l}\text { Prevailing Redox } \\
\text { Conditions }\end{array}$} & anoxic & & & anoxic & anoxic-su & oxic & oxic \\
\hline
\end{tabular}

Note: * DOC concentration after ozonation. 


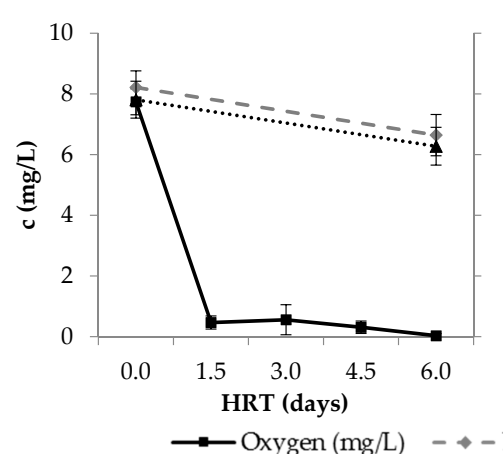

(a)

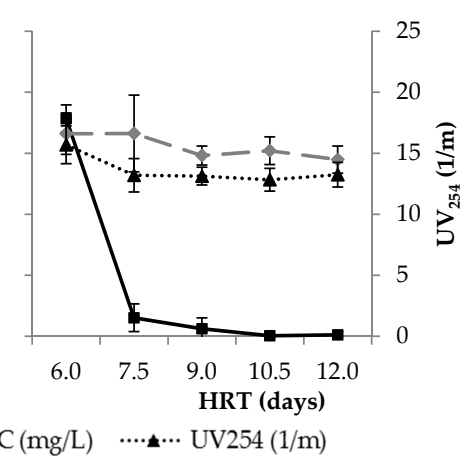

(b)

Figure 2. DOC, oxygen and $\mathrm{UV}_{254}$ absorbance (a) in the first column as an average from four different systems and $(\mathbf{b})$ in the second filtration step after aeration with air $(n \geq 5)$.

\subsection{Removal of Bulk Organic Parameters}

DOC and oxygen concentrations as well as the $U^{254}$ values within the first infiltration (a) and in the column after aeration with air (b) are shown in Figure 2. Results after aeration with pure oxygen and ozone are given in Figure S1 in the supplementary material. In the first filtration step, oxygen was completely consumed after 1.5 days of infiltration and $1.6 \pm 0.5 \mathrm{mg} / \mathrm{L}$ DOC $(19 \%)$ were attenuated (Figure 2a). After the aeration with air, the oxygen concentration increased up to $7.1 \pm 0.5 \mathrm{mg} / \mathrm{L}$, but was also degraded within the first couple of days (Figure $2 \mathrm{~b}$ ). The DOC degradation of $0.8 \pm 0.5 \mathrm{mg} / \mathrm{L}(10 \%)$ was significantly higher as compared to the system $\mathrm{BF}$. The $\mathrm{UV}_{254}$ decreased from $15.7 \pm 1.6$ to $13.2 \pm 1.0 \mathrm{~m}^{-1}$ after aeration (Figure $2 \mathrm{~b}$ ). The SUVA did not significantly change after aeration with air between column influent and effluent (SUVA $=2.3 \pm 0.2 \mathrm{~L} /(\mathrm{m} \cdot \mathrm{mg})$ ).

A mass balance of dissolved oxygen and inorganic compounds $\left(1.0 \mathrm{mg} \mathrm{NO}_{2}{ }^{-} \mathrm{N} \hat{=} 1.14 \mathrm{mg} \mathrm{O}_{2}\right.$; $1.0 \mathrm{mg} \mathrm{Mn}{ }^{2+} \hat{=} 0.29 \mathrm{mg} \mathrm{O}_{2}$ ) resulted in oxygen consumption of approximately $6.6 \mathrm{mg} / \mathrm{L}$ by organic compounds. Since the observed DOC removal is too low $(0.8 \pm 0.5 \mathrm{mg} / \mathrm{L})$ to account for this oxygen consumption, it is hypothesized that transformation of particular organic carbon (POC) present within the sand column might have contributed to the overall oxygen consumption. Similar results indicating that the targeted oligotrophic conditions were not fully established after aeration were also obtained from other columns (first filtration step, systems SMART $\mathrm{O}_{2}$ and SMART $\mathrm{O}_{3}$ ).

The aeration with oxygen provided oxic conditions throughout the system (Table 1) and improved the DOC removal as well as the $\mathrm{UV}_{254}$ reduction compared to aeration with air (Figure 3). These results confirm the limitation of DOC degradation in the aerated system due to a limited availability of dissolved oxygen.

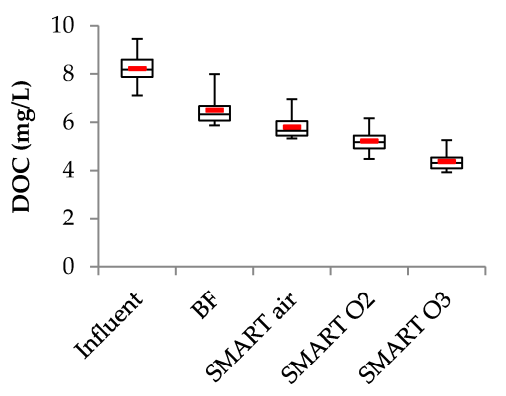

(a)

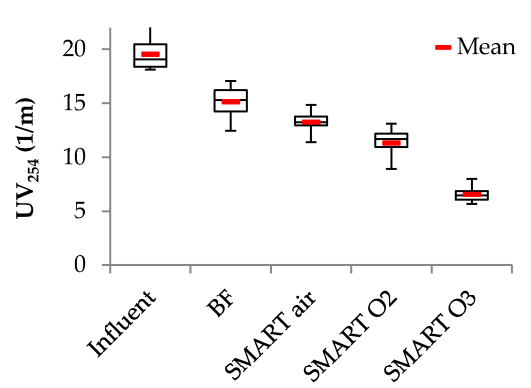

(b)

Figure 3. DOC concentrations (a) and $\mathrm{UV}_{254}$ absorbance values (b) of the influent and the effluents of all four systems: Bank filtration (BF), sequential managed aquifer recharge technology (SMART) air, SMART $\mathrm{O}_{2}$, SMART $\mathrm{O}_{3}(n \geq 16)$. Whiskers indicate maximum and minimum values. 
Ozonation of the effluent from the first column resulted also in oxic conditions throughout the subsequent column system (Table 1). During ozonation, DOC and $\mathrm{UV}_{254}$ decreased from $6.6 \pm 0.7$ to $6.3 \pm 0.5 \mathrm{mg} / \mathrm{L}$ and from $15.7 \pm 1.6$ to $9.5 \pm 0.9 \mathrm{~m}^{-1}$, respectively. Ozonation also further enhanced the DOC degradation by $24 \%$, likely due to the formation of biodegradable compounds during oxidation reactions with ozone [24]. However, in our experiments, elevated ozone dosages were needed due to the consumption of reduced inorganic compounds such as nitrite and manganese. For planning of full-scale operation, the effects of these reduced compounds regarding oxidation demand need to be considered.

\subsection{Transformation of Trace Organic Chemicals as a Function of Different Oxidation Techniques}

TOrCs are discussed in the following section regarding their degradation efficiencies in different filtration systems as a function of the aeration technique applied. The influent concentrations, the limits of quantification (LOQ) as well as the second-order rate constants for the reactions of the compounds with ozone or $\cdot \mathrm{OH}$-radicals, respectively $\left(\mathrm{k}_{\mathrm{O} 3}\right.$ and $\left.\mathrm{k}_{\mathrm{OH}}\right)$ of all quantified TOrCs are given in Table S1. The results of the TOrCs which could be detected after the first filtration step are shown in Figure 4. Furthermore, the transformation of these compounds as a function of the HRT in the second systems after aeration with air, pure oxygen or ozone, respectively, are given in Figure S2 in the supplementary material.

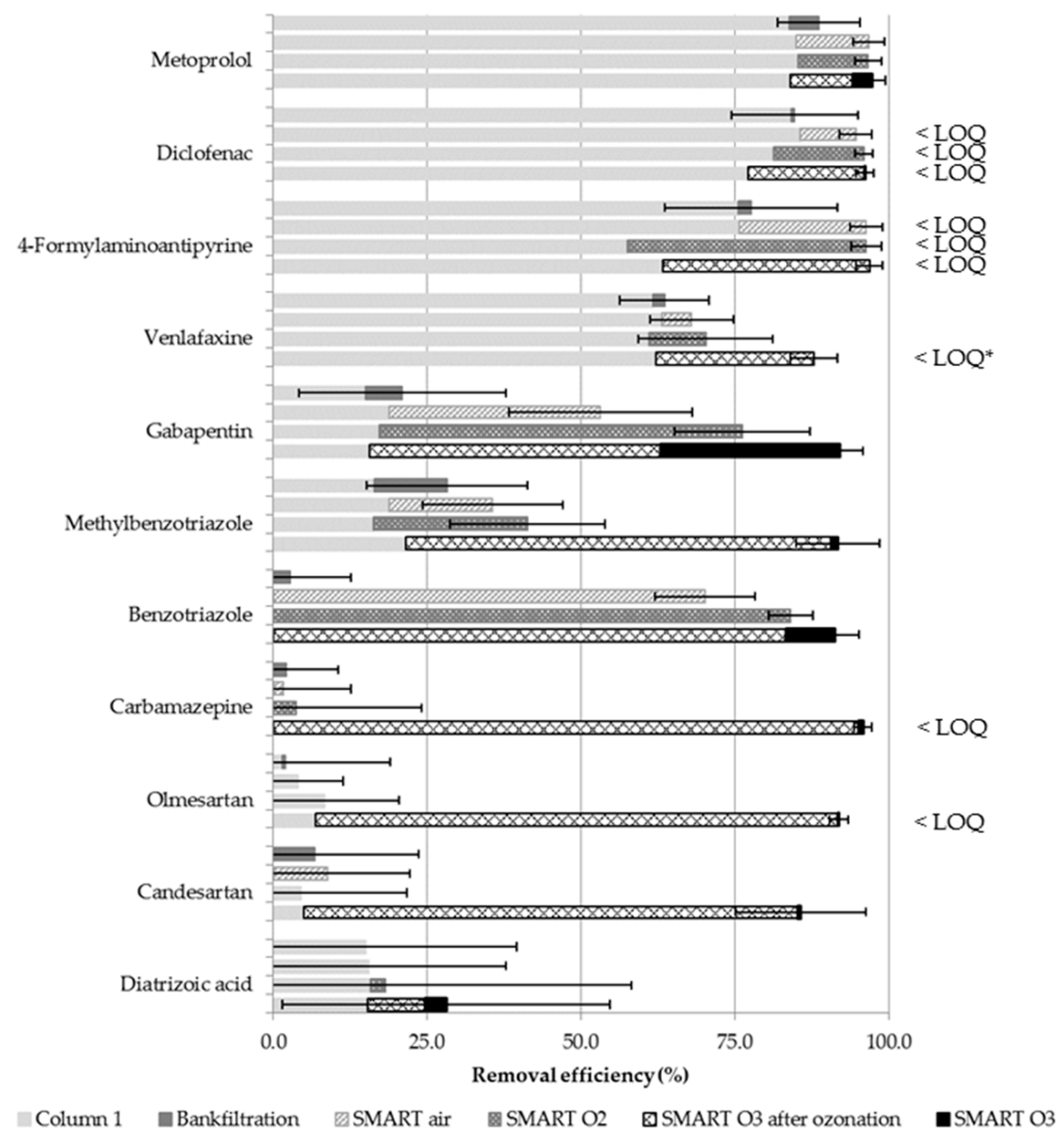

Figure 4. Removal efficiency (\%) of all quantified trace organic chemicals (TOrCs) which were not degraded below the limits of quantification (LOQ) in the first column $(n \geq 8)$. (*Venlafaxine was degraded below LOQ during ozonation whereas an increase of the concentration up to $65 \pm 13 \mathrm{ng} / \mathrm{L}$ in the following filtration step was observed.) 


\subsubsection{Consistency and Reproducibility of Observed Degradation}

The influent concentrations of all quantified TOrCs decreased during the experimental period. This may be explained due to decreasing TOrCs concentrations in the Lake Tegel, Berlin, since the effluent from the WWTP Schönerlinde, Berlin, was only partly discharged into local channel flowing to Lake Tegel during the experiments. Detailed results from measurements of the antibiotic sulfamethoxazole shown in Figure 5 revealed an increased compound removal by time, likely indicating the adaptation of bacteria for sulfamethoxazole biodegradation. After three months, the effluent concentration of the SMART air system was below the LOQ $(50 \mathrm{ng} / \mathrm{L})$ with one exception ( $c=108 \mathrm{ng} / \mathrm{L}$ ). These results are in line with previous findings reported by Baumgarten et al. [29], who observed a long adaption time of more than two years for an efficient degradation of sulfamethoxazole ( $60 \%$ under oxic conditions, no degradation under anaerobic conditions). In contrast to experiments from Baumgarten et al. [29], columns were filled with sand from the infiltration basin and operated at higher temperatures, which might have shortened the need for an extended adaptation period. The observed increase through the column passage in the first weeks could be caused by analytical inaccuracies, but also formation of sulfamethoxazole from conjugated metabolites (e.g., $\mathrm{N}^{4}$-acetylsulfamethoxazole) as previously reported from WWTPs might play a role [30,31]. Similar to sulfamethoxazole, gabapentin showed a slightly increasing transformation in the SMART air system during the experimental period.

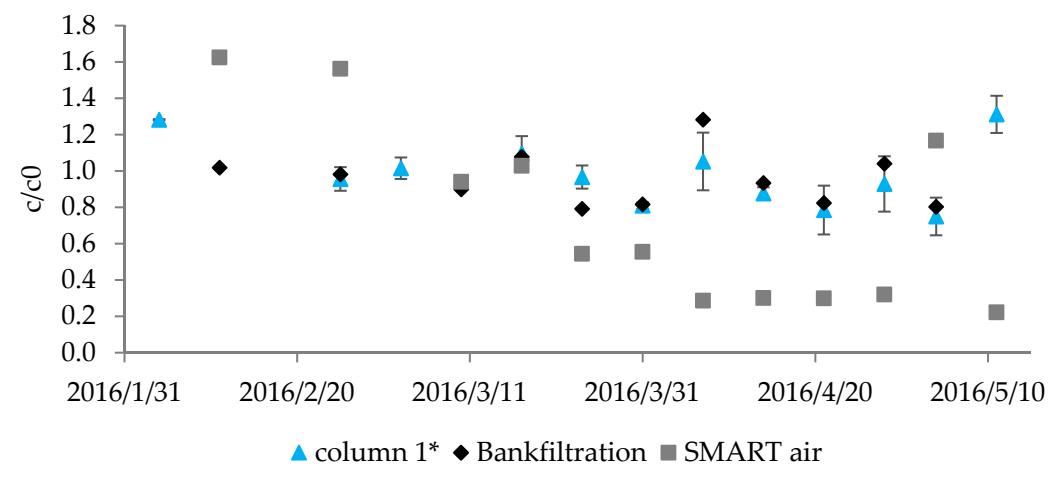

Figure 5. Improved removal efficiency of sulfamethoxazole in the SMART air system; * mean value of first column effluents, $n=2$.

Transformation of diclofenac was already observed in the first filtration step and increased during the period of adaption up to a removal below the LOQ $(100 \mathrm{ng} / \mathrm{L})$ at the end of the experiment. The transformation of the other targeted TOrCs was consistent during the experiment despite decreasing influent concentrations. Results from the different column systems are summarized as average removal with standard deviation in Figure 4.

\subsubsection{Compound Removal during Anoxic Infiltration}

The compounds acesulfame, iomeprol, iopromide, and valsartan were transformed to concentrations below the LOQ in the first filtration step (Table S1). It has to be noted that the influent concentrations were close to or even partly below the LOQ for acesulfame and valsartan, respectively. While rapid degradation of iomeprol and iopromid is known from bank filtration and groundwater recharge sites [15,32,33], efficient removal of acesulfame and valsartan was not expected. Acesulfame has been reported as a rather persistent compound and was even proposed as a conservative wastewater marker [34-36]. However, Zucker et al. also revealed efficient degradation of acesulfame under certain (mostly oxic) conditions [37]. For valsartan, ubiquitous occurrence in the aquatic environment as well as low to moderate biodegradation has been reported $[5,38]$. Similar to acesulfame, valsartan has been proposed as a wastewater marker in the environment [39]. To the best 
of our knowledge, this study reports for the first time, efficient elimination of this compound in MAR systems. Good removal ( $>70 \%)$ in the reference system under anoxic conditions was also observed for diclofenac, 4-Formylaminoantipyrine, and metoprolol. For these compounds, degradation mainly occurred in the first column, indicating more efficient removal during initial infiltration characterized by high microbial activity.

\subsubsection{TOrC Removal during SMART}

The systems SMART air and SMART $\mathrm{O}_{2}$ performed equal or better than the reference system for most compounds. Especially the removal of diclofenac, 4-Formylaminoantipyrine, benzotriazole, gabapentin, venlafaxine and metoprolol was significantly enhanced using the sequential approach (students $t$-test, paired, $\alpha<0.05$ ). Further improvement of benzotriazole and gabapentin removal by using pure oxygen confirmed potential oxygen limitation in the second column after aeration with air. However, for efficient removal of most compounds, the establishment of fully oxic conditions throughout infiltration was obviously not needed, indicating a limited benefit from using pure oxygen for intermediate aeration.

4-Formylaminoantipyrine as a human metabolite of phenazone-type pharmaceuticals [14] was removed by $76 \%$ in the first column of the reference system with no significant increase with ongoing filtration under anoxic conditions (students $t$-test, paired, $\alpha=0.18$ ). All SMART systems exhibited an efficient degradation of 4-Formylaminoantipyrine below the LOQ $(100 \mathrm{ng} / \mathrm{L})$ which implies a removal of $>96 \%$. These results confirm previous results suggesting a degradation of 4-Formylaminoantipyrine under oxic conditions of $94 \%$ [32].

The removal of diclofenac in the system BF did not increase significantly compared to the first filtration step (students $t$-test, paired, $\alpha=0.37$ ), whereas in the SMART air and SMART $\mathrm{O}_{2}$ system a significantly enhanced and consistent transformation was observed (students $t$-test, paired, $\alpha<0.05$ ). In SMART air, the concentration dropped below the LOQ $(100 \mathrm{ng} / \mathrm{L})$ with two exceptions. In the $\mathrm{SMART}_{2}$ system, the concentration consistently decreased below the LOQ. Wiese et al. [32] confirmed degradation under oxic conditions for diclofenac of $>90 \%$, whereas Rauch-Williams et al. [18] reported a faster removal under anoxic conditions. Our findings are in accordance to Regnery et al. [20], who proposed no complete removal of diclofenac during a short riverbank filtration but a rapid transformation in the second filtration step after reaeration.

Previous studies reported different behaviors of benzotriazole biodegradation during MAR ranging from highly persistent to microbial processes [40] over preferred biodegradation under oxic conditions to biodegradation even under anoxic conditions with biodegradation half-lives of $29 \pm 2$ days [41,42]. However, our results confirm biodegradation under oxic conditions whereas no removal was achieved under anoxic conditions (Figure 4).

Biotransformation is the most likely degradation mechanism in wastewater treatment plants for metoprolol compared to sorption as shown by Maurer et al. [43]. Different studies revealed an efficient removal of metoprolol in MAR or slow sand filters, respectively [44-46]. Here, metoprolol was degraded by $84 \%$ in the first filtration step and overall by $89 \%$ in the reference system not employing an intermediate treatment. Aeration increased elimination up to $97 \%$ independently of the type of aeration technique employed.

Previous studies argue that gabapentin is persistent during SAT simulated in laboratory-scale soil column set-ups [47]. While the removals of gabapentin in the reference system (21\%) support these findings (Figure 4), the removal efficiency of gabapentin under oxic conditions was significantly enhanced (53\% in SMART air; $76 \%$ in SMART $\mathrm{O}_{2}$ ). As shown in Figure 6, gabapentin was only eliminated within the first 1.5 days after aeration with air, which corresponds to the fast oxygen consumption in the SMART air system. The fully oxic SMART $\mathrm{O}_{2}$ led to a continuous gabapentin degradation, which remained constant after 4.5 days post aeration. These results support the argument that gabapentin is very redox sensitive and could be degraded $>53 \%$ under oxic conditions. However, it remains unclear, why initial removal after aeration with air was faster than in the fully oxic system. 


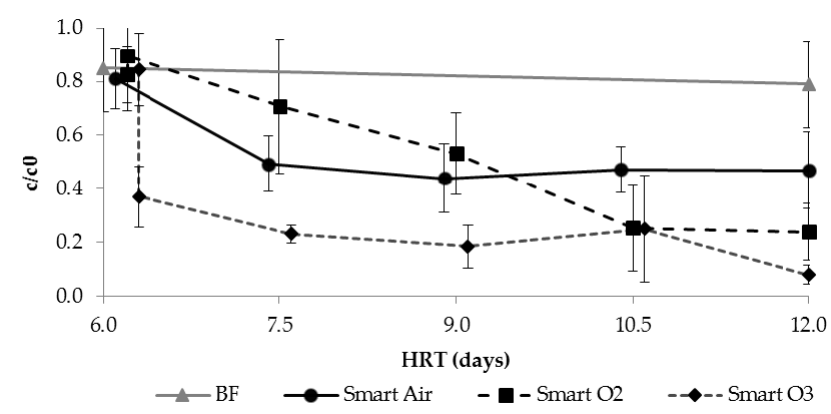

Figure 6. Degradation of gabapentin in the second filtration step of all four systems: BF, SMART air, SMART $\mathrm{O}_{2}$ and SMART $\mathrm{O}_{3}(n \geq 2)$.

Despite improved performance, removal of several compounds, such as benzotriazole, methylbenzotriazole, venlafaxine and sulfamethoxazole is still not effective and necessitates further improvement. In addition, compounds persistent to biodegradation such as carbamazepine, candesartan, olmesartan, and diatrizoic acid are not removed by SMART.

\subsubsection{Application of Ozone for Intermediate Aeration and Oxidation}

All TOrCs that were present after the first column infiltration were subject to oxidative transformation using ozonation. The removal efficiency of single substances depends on their reactivity with ozone. In previous research, compounds were separated into fast reacting compounds with apparent second order rate constants of $\mathrm{k}_{\mathrm{O} 3}>10^{4} \mathrm{M}^{-1} \cdot \mathrm{s}^{-1}(\mathrm{pH}=7)$, moderately $\left(10^{2} \mathrm{M}^{-1} \cdot \mathrm{s}^{-1}<\mathrm{k}_{\mathrm{O} 3}<\right.$ $\left.10^{4} \mathrm{M}^{-1} \cdot \mathrm{s}^{-1} ; \mathrm{pH}=7\right)$, and slowly reacting compounds $\left(\mathrm{k}_{\mathrm{O} 3}<10^{2} \mathrm{M}^{-1} \cdot \mathrm{s}^{-1}\right)[21,46]$. The rate constants of all quantified compounds are summarized in Table S1. Removal of fast reacting TOrCs is dominated by direct reaction with ozone leading to a complete transformation of the parent compound at typically applied ozone dosages. In this study, the fast reacting compounds diclofenac, sulfamethoxazole, carbamazepine and venlafaxine were mainly removed below the limit of quantification although specific ozone consumption was relatively low $\left(0.6 \pm 0.1 \mathrm{mg} \mathrm{O}_{3} / \mathrm{mg} \mathrm{DOC}, n=12\right)$. Despite removal below LOQ during ozonation, the compound venlafaxine was consistently detected in the effluent of the subsequent column at concentrations of $65 \pm 13 \mathrm{ng} / \mathrm{L}$. A reverse reaction from ozonation transformation products can be assumed as being the reason for this increase. The major transformation product from the reaction with ozone is venlafaxine $\mathrm{N}$-oxide [48]. Although a reduction seems unlikely under oxic conditions, a similar pathway has been reported for other N-oxides [49,50]. More research is certainly needed to better understand these processes.

Moderately reacting compounds are oxidized by both, ozone and $\mathrm{OH}$-radicals which are formed from ozone reactions with the water matrix [51]. Benzotriazole and methylbenzotriazole were removed by approximately $80 \%$ during ozonation within this study. Removal of these compounds could be easily enhanced by increasing ozone dosages to compensate high oxygen consumption by nitrite and $\mathrm{Mn}$ (II). Average concentrations of $0.2 \mathrm{mg} / \mathrm{L} \mathrm{NO}_{2}{ }^{-}-\mathrm{N}$ and $1.0 \mathrm{mg} / \mathrm{L} \mathrm{Mn}(\mathrm{II})$ consume 0.7 and $0.9 \mathrm{mg} / \mathrm{L}$ ozone, respectively, since they are completely oxidized during ozonation due to high second-order rate constants with ozone $\left(\mathrm{k}_{\mathrm{O} 3}\left(\mathrm{NO}_{2}{ }^{-}\right)=3.7 \times 10^{5} \mathrm{M}^{-1} \cdot \mathrm{s}^{-1} ; \mathrm{k}_{\mathrm{O} 3}(\mathrm{Mn}(\mathrm{II}))=1.5 \times 10^{3} \mathrm{M}^{-1} \cdot \mathrm{s}^{-1}\right.$ [52] $)$.

Due to the formation of OH-radicals from the reactions of ozone in natural waters, also compounds, which are not reactive to ozone can be oxidized during ozonation. However, removal of these TOrCs is usually incomplete and variable depending on compound's reactivity with $\mathrm{OH}$-radicals. In this study, gabapentin was removed by approximately $50 \%$ during ozonation. Together with improved biodegradation due to intermediate aeration, this compound could be eliminated close to the LOQ ( $50 \mathrm{ng} / \mathrm{L}$ ) by the combination of sequential managed aquifer recharge with intermediate ozonation.

In contrast, the second-order rate constant for the reaction of diatrizoic acid with OH-radicals is comparatively low resulting in limited removal of $9 \%$ by ozonation [53]. Since this compound is also not efficiently biodegraded in soil columns, overall removal was below $30 \%$ in all investigated 
hybrid systems. These results demonstrate that some compounds can even persist during combined ozonation and biological treatment processes. This has previously also been observed for other TOrCs such as primidone [46].

To the best of our knowledge, less is known about the rate constants of candesartan and olmesartan. It is assumed, that candesartan is a moderately reacting compound since its removal of $80 \%$ is similar to benzotriazole, whereas a fast removal of olmesartan below the LOQ $(500 \mathrm{ng} / \mathrm{L})$ was observed. The rapid degradation of olmesartan by ozone could probably be explained by the electron rich olefin group of the imidazole side chain.

It is well understood that ozonation does not result in mineralization of TOrCs but leads to a formation of transformation products. The potential removal of these products in biological treatment processes was reviewed by Hübner et al. [54] and is not part of this study. As a short summary, reactions of ozone with olefinic groups and electron-rich aromatic moieties mostly involve the cleavage of double bonds and aromatic rings resulting in better biodegradable products. In contrast, transformation of amines and sulfur-containing chemicals might also form highly persistent products. Further investigations are needed to analyze the relevance of transformation products in combined ozonation and MAR systems.

\subsubsection{Formation and Fate of the Transformation Product Valsartan Acid}

During oxidative and biological treatment, compounds are often not mineralized but just transformed. Valsartan acid is a known transformation product from biodegradation of different sartanes such as valsartan, irbesartan, candesartan, and olmesartan [55]. In Figure 7a, changes of molar concentrations of valsartan, olmesartan, candesartan, and valsartan acid in the first filtration step are illustrated. Effluent concentrations of each compound of the first filtration step are summarized as mean values. Valsartan was transformed immediately below the LOQ of $100 \mathrm{ng} / \mathrm{L}$ in the first columns, whereas candesartan and olmesartan were persistent (also in the second columns of the systems BF, SMART air and SMART $\mathrm{O}_{2}$, Figure S2). Although the decrease of valsartan came along with an increase of valsartan acid, formation of valsartan acid cannot be solely attributed to transformation of valsartan. It is suggested that degradation of other compounds such as irbesartan, which was not analyzed, might have contributed to valsartan acid formation [55]. In the second infiltration step, valsartan acid is efficiently attenuated in all systems with aeration (SMART air: 95\%, SMART O $\mathrm{O}_{2} / \mathrm{O}_{3}:>99 \%$ ), whereas it remained constant in the anoxic reference system (Figure $7 \mathrm{~b}$ ). These results are in accordance to Nödler et al. [45], who proposed poor removal of valsartan acid during bank filtration. Oxic conditions seem to be favored for a sufficient biodegradation of valsartan acid.

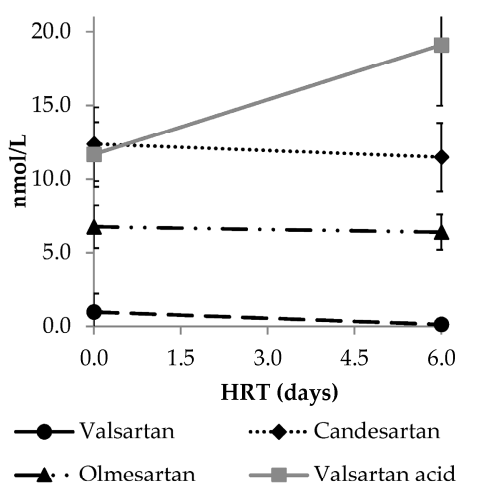

(a)

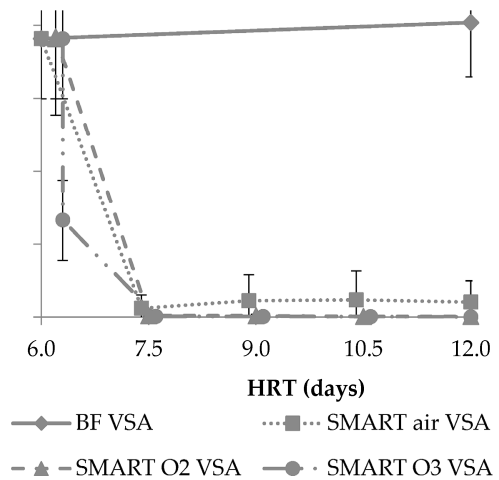

(b)

Figure 7. The formation of valsartan acid (VSA) in the first filtration step (grey line, a) and the transformation of valsartan, candesartan and olmesartan (black lines, a). Valsartan acid was degraded in the second filtration step after aeration with air, oxygen or ozonation (b) $n \geq 4$. 


\section{Conclusions}

The performance of the SMART concept as a combination of two MAR systems with an intermediate aeration step was compared to a conventional MAR system such as riverbank filtration. Different oxidants were tested between both filtration steps (i.e., air, pure oxygen, ozone) and investigated regarding the removal efficiency of select TOrCs. Rapid oxygen consumption, nitrate reduction and dissolution of manganese confirmed anoxic conditions within the first filtration step. Aeration with air did not result in sufficient oxygen concentrations to establish oxic conditions throughout the second column, resulting in oxygen limitation for DOC degradation in comparison to fully oxic column after aeration with pure oxygen. Ozonation increased the biodegradability of DOC, enhancing overall removal to $47 \%$.

Most TOrCs were equally or better degraded in sequential systems with intermediate aeration compared to the single step bank filtration system. The compounds acesulfam, iomeprol, iopromide, and valsartan were degraded within the first infiltration step despite the fast oxygen consumption and prevailing anoxic conditions. Intermediate aeration resulted in the significantly enhanced removal of diclofenac, 4-Formylaminoantipyrine, metoprolol, gabapentin, venlafaxine, valsartan acid and benzotriazole. Among them, degradation of the compounds gabapentin and benzotriazole was still limited in the partly suboxic system after aeration and could be further enhanced under fully oxic conditions. Intermediate ozonation led to a significant degradation of the biological persistent compounds carbamazepine, candesartan, and olmesartan. Additionally, the attenuation of gabapentin, methylbenzotriazole, benzotriazole and venlafaxine was further increased. However, results also demonstrated that a few compounds (i.e., diatrizoic acid) are not efficiently removed in an ozone-MAR hybrid system.

Supplementary Materials: The following are available online at www.mdpi.com/2073-4441/9/3/221/s1, Table S1: List of quantified TOrCs.; Figure S1: Profile data of the DO, DOC and $\mathrm{UV}_{254}$ measurements of the systems SMART $\mathrm{O}_{2}$ and SMART $\mathrm{O}_{3}$ after aeration with pure oxygen or ozone, respectively $(n \geq 4)$; Figure S2: Profile data of the systems SMART air, SMART O2 and SMART O3 after aeration with air, pure oxygen or ozone, respectively, of all quantified TOrCs with effluent concentrations of the first filtration step > LOQ despite sulfamethoxazole.

Acknowledgments: The Berliner Wasserbetriebe (BWB) are gratefully acknowledged for financial support of this study. This publication was supported by the German Research Foundation (DFG) and the Technical University of Munich (TUM) in the framework of the Open Access Publishing Program.

Author Contributions: Karin Hellauer, Aki S. Ruhl, Uwe Hübner, Martin Jekel and Jörg E. Drewes conceived and designed the experiment; Dorothea Mergel, Karin Hellauer and Josefine Filter performed the experiments; Dorothea Mergel and Karin Hellauer analyzed the data; Josefine Filter, Aki S. Ruhl and Martin Jekel contributed reagents, materials and analysis tools; Aki S. Ruhl performed the HPLC-MS/MS analysis; Karin Hellauer wrote the paper Jörg E. Drewes and Uwe Hübner supervised this study and reviewed the manuscript. The final version was approved by all authors.

Conflicts of Interest: The authors declare no conflict of interest. The founding sponsors had no role in the design of the study; in the collection, analyses, or interpretation of data; in the writing of the manuscript, and in the decision to publish the results.

\section{References}

1. Schwarzenbach, R.P.; Escher, B.I.; Fenner, K.; Hofstetter, T.B.; Johnson, C.A.; von Gunten, U.; Wehrli, B. The Challenge of Micropollutants in Aquatic Systems. Science 2006, 313, 1072-1077. [CrossRef] [PubMed]

2. Li, W.C. Occurrence, sources, and fate of pharmaceuticals in aquatic environment and soil. Environ. Pollut. 2014, 187, 193-201. [CrossRef] [PubMed]

3. Luo, Y.; Guo, W.; Ngo, H.H.; Nghiem, L.D.; Hai, F.I.; Zhang, J.; Liang, S.; Wang, X.C. A review on the occurrence of micropollutants in the aquatic environment and their fate and removal during wastewater treatment. Sci. Total Environ. 2014, 473-474, 619-641. [CrossRef] [PubMed]

4. Petrie, B.; Barden, R.; Kasprzyk-Hordern, B. A review on emerging contaminants in wastewaters and the environment: Current knowledge, understudied areas and recommendations for future monitoring. Water Res. 2015, 72, 3-27. [CrossRef] [PubMed] 
5. Kasprzyk-Hordern, B.; Dinsdale, R.M.; Guwy, A.J. The occurrence of pharmaceuticals, personal care products, endocrine disruptors and illicit drugs in surface water in South Wales, UK. Water Res. 2008, 42, 3498-3518. [CrossRef] [PubMed]

6. Benotti, M.J.; Trenholm, R.A.; Vanderford, B.J.; Holady, J.C.; Stanford, B.D.; Snyder, S.A. Pharmaceuticals and Endocrine Disrupting Compounds in U.S. Drinking Water. Environ. Sci. Technol. 2009, 43, 597-603. [CrossRef] [PubMed]

7. Glassmeyer, S.T.; Furlong, E.T.; Kolpin, D.W.; Cahill, J.D.; Zaugg, S.D.; Werner, S.L.; Meyer, M.T.; Kryak, D.D. Transport of Chemical and Microbial Compounds from Known Wastewater Discharges: Potential for Use as Indicators of Human Fecal Contamination. Environ. Sci. Technol. 2005, 39, 5157-5169. [CrossRef] [PubMed]

8. Heberer, T. Tracking persistent pharmaceutical residues from municipal sewage to drinking water. J. Hydrol. 2002, 266, 175-189. [CrossRef]

9. Missimer, T.M.; Drewes, J.E.; Maliva, R.G.; Amy, G. Aquifer Recharge and Recovery: Groundwater Recharge Systems for Treatment, Storage, and Water Reclamation. Ground Water 2011, 49, 771. [CrossRef] [PubMed]

10. Amy, G.; Drewes, J.E. Soil Aquifer Treatment (SAT) as a Natural and Sustainable Wastewater Reclamation/Reuse Technology: Fate of Wastewater Effluent Organic Matter (EfOM) and Trace Organic Compounds. Environ. Monit. Assess. 2007, 129, 19-26. [CrossRef] [PubMed]

11. Tufenkji, N.; Ryan, J.N.; Elimelech, M. The Promise of Bank Filtration. Environ. Sci. Technol. 2002, 36, 422A-428A. [CrossRef] [PubMed]

12. Hoppe-Jones, C.; Oldham, G.; Drewes, J.E. Attenuation of total organic carbon and unregulated trace organic chemicals in U.S. riverbank filtration systems. Water Res. 2010, 44, 4643-4659. [CrossRef] [PubMed]

13. Alidina, M.; Li, D.; Drewes, J.E. Investigating the role for adaptation of the microbial community to transform trace organic chemicals during managed aquifer recharge. Water Res. 2014, 56, 172-180. [CrossRef] [PubMed]

14. Massmann, G.; Dünnbier, U.; Heberer, T.; Taute, T. Behaviour and redox sensitivity of pharmaceutical residues during bank filtration-Investigation of residues of phenazone-type analgesics. Chemosphere 2008, 71, 1476-1485. [CrossRef] [PubMed]

15. Grünheid, S.; Amy, G.; Jekel, M. Removal of bulk dissolved organic carbon (DOC) and trace organic compounds by bank filtration and artificial recharge. Water Res. 2005, 39, 3219-3228. [CrossRef] [PubMed]

16. Li, D.; Alidina, M.; Ouf, M.; Sharp, J.O.; Saikaly, P.; Drewes, J.E. Microbial community evolution during simulated managed aquifer recharge in response to different biodegradable dissolved organic carbon (BDOC) concentrations. Water Res. 2013, 47, 2421-2430. [CrossRef] [PubMed]

17. Hoppe-Jones, C.; Dickenson, E.R.V.; Drewes, J.E. The role of microbial adaptation and biodegradable dissolved organic carbon on the attenuation of trace organic chemicals during groundwater recharge. Sci. Total Environ. 2012, 437, 137-144. [CrossRef] [PubMed]

18. Rauch-Williams, T.; Hoppe-Jones, C.; Drewes, J.E. The role of organic matter in the removal of emerging trace organic chemicals during managed aquifer recharge. Water Res. 2010, 44, 449-460. [CrossRef] [PubMed]

19. Regnery, J.; Barringer, J.; Wing, A.D.; Hoppe-Jones, C.; Teerlink, J.; Drewes, J.E. Start-up performance of a full-scale riverbank filtration site regarding removal of DOC, nutrients, and trace organic chemicals. Chemosphere 2015, 127, 136-142. [CrossRef] [PubMed]

20. Regnery, J.; Wing, A.D.; Kautz, J.; Drewes, J.E. Introducing sequential managed aquifer recharge technology (SMART) -From laboratory to full-scale application. Chemosphere 2016, 154, 8-16. [CrossRef] [PubMed]

21. Hollender, J.; Zimmermann, S.G.; Koepke, S.; Krauss, M.; McArdell, C.S.; Ort, C.; Singer, H.; von Gunten, U.; Siegrist, H. Elimination of organic micropollutants in a municipal wastewater treatment plant upgraded with a full-scale post-ozonation followed by sand filtration. Environ. Sci. Technol. 2009, 43, 7862-7869. [CrossRef] [PubMed]

22. Huber, M.M.; Göbel, A.; Joss, A.; Hermann, N.; Löffler, D.; McArdell, C.S.; Ried, A.; Siegrist, H.; Ternes, T.A.; von Gunten, U. Oxidation of Pharmaceuticals during Ozonation of Municipal Wastewater Effluents: A Pilot Study. Environ. Sci. Technol. 2005, 39, 4290-4299. [CrossRef] [PubMed]

23. Kozyatnyk, I.; Swietlik, J.; Raczyk-Stanislawiak, U.; Dabrowska, A.; Klymenko, N.; Nawrocki, J. Influence of oxidation on fulvic acids composition and biodegradability. Chemosphere 2013, 92, 1335-1342. [CrossRef] [PubMed]

24. Hammes, F.; Salhi, E.; Köster, O.; Kaiser, H.-P.; Egli, T.; von Gunten, U. Mechanistic and kinetic evaluation of organic disinfection by-product and assimilable organic carbon (AOC) formation during the ozonation of drinking water. Water Res. 2006, 40, 2275-2286. [CrossRef] [PubMed] 
25. Hübner, U.; Kuhnt, S.; Jekel, M.; Drewes, J.E. Fate of bulk organic carbon and bromate during indirect water reuse involving ozone and subsequent aquifer recharge. J. Water Reuse Desalin. 2016, 6, 413-420. [CrossRef]

26. Zietzschmann, F.; Worch, E.; Altmann, J.; Ruhl, A.S.; Sperlich, A.; Meinel, F.; Jekel, M. Impact of EfOM size on competition in activated carbon adsorption of organic micro-pollutants from treated wastewater. Water Res. 2014, 65, 297-306. [CrossRef] [PubMed]

27. Massmann, G.; Nogeitzig, A.; Taute, T.; Pekdeger, A. Seasonal and spatial distribution of redox zones during lake bank filtration in Berlin, Germany. Environ. Geol. 2008, 54, 53-65. [CrossRef]

28. Regnery, J.; Wing, A.; Alidina, M.; Drewes, J.E. Biotransformation of trace organic chemicals during groundwater recharge: How useful are first-order rate constants? J. Contam. Hydrol. 2015, 179, 65-75. [CrossRef] [PubMed]

29. Baumgarten, B.; Jährig, J.; Reemtsma, T.; Jekel, M. Long term laboratory column experiments to simulate bank filtration: Factors controlling removal of sulfamethoxazole. Water Res. 2011, 45, 211-220. [CrossRef] [PubMed]

30. Göbel, A.; Thomsen, A.; McArdell, C.S.; Joss, A.; Giger, W. Occurrence and Sorption Behavior of Sulfonamides, Macrolides, and Trimethoprim in Activated Sludge Treatment. Environ. Sci. Technol. 2005, 39, 3981-3989. [CrossRef] [PubMed]

31. Polesel, F.; Andersen, H.R.; Trapp, S.; Plosz, B.G. Removal of Antibiotics in Biological Wastewater Treatment Systems-A Critical Assessment Using the Activated Sludge Modeling Framework for Xenobiotics (ASM-X). Environ. Sci. Technol. 2016, 50, 10316-10334. [CrossRef] [PubMed]

32. Wiese, B.; Massmann, G.; Jekel, M.; Heberer, T.; Dünnbier, U.; Orlikowski, D.; Grützmacher, G. Removal kinetics of organic compounds and sum parameters under field conditions for managed aquifer recharge. Water Res. 2011, 45, 4939-4950. [CrossRef] [PubMed]

33. Kormos, J.L.; Schulz, M.; Ternes, T.A. Occurrence of iodinated X-ray contrast media and their biotransformation products in the urban water cycle. Environ. Sci. Technol. 2011, 45, 8723-8732. [CrossRef] [PubMed]

34. Buerge, I.J.; Buser, H.-R.; Kahle, M.; Müller, M.D.; Poiger, T. Ubiquitous Occurrence of the Artificial Sweetener Acesulfame in the Aquatic Environment: An Ideal Chemical Marker of Domestic Wastewater in Groundwater. Environ. Sci. Technol. 2009, 43, 4381-4385. [CrossRef] [PubMed]

35. Scheurer, M.; Storck, F.R.; Graf, C.; Brauch, H.-J.; Ruck, W.; Lev, O.; Lange, F.T. Correlation of six anthropogenic markers in wastewater, surface water, bank filtrate, and soil aquifer treatment. J. Environ. Monit. 2011, 13, 966-973. [CrossRef] [PubMed]

36. Wolf, L.; Zwiener, C.; Zemann, M. Tracking artificial sweeteners and pharmaceuticals introduced into urban groundwater by leaking sewer networks. Sci. Total Environ. 2012, 430, 8-19. [CrossRef] [PubMed]

37. Zucker, I.; Mamane, H.; Cikurel, H.; Jekel, M.; Hübner, U.; Avisar, D. A hybrid process of biofiltration of secondary effluent followed by ozonation and short soil aquifer treatment for water reuse. Water Res. 2015, 84, 315-322. [CrossRef] [PubMed]

38. Nödler, K.; Tsakiri, M.; Licha, T. The impact of different proportions of a treated effluent on the biotransformation of selected micro-contaminants in river water microcosms. Int. J. Environ. Res. Public Health 2014, 11, 10390-10405. [CrossRef] [PubMed]

39. Nödler, K.; Tsakiri, M.; Aloupi, M.; Gatidou, G.; Stasinakis, A.S.; Licha, T. Evaluation of polar organic micropollutants as indicators for wastewater-related coastal water quality impairment. Environ. Pollut. 2016, 211, 282-290. [CrossRef] [PubMed]

40. Breedveld, G.D.; Roseth, R.; Sparrevik, M.; Hartnig, T.; Hem, L.J. Persistence of the De-Icing Additive Benzotriazole at an Abandoned Airport. Water Air Soil Pollut. Focus 2003, 3, 91-101. [CrossRef]

41. Liu, Y.-S.; Ying, G.-G.; Shareef, A.; Kookana, R.S. Biodegradation of three selected benzotriazoles under aerobic and anaerobic conditions. Water Res. 2011, 45, 5005-5014. [CrossRef] [PubMed]

42. Alotaibi, M.D.; Patterson, B.M.; McKinley, A.J.; Reeder, A.Y.; Furness, A.J.; Donn, M.J. Fate of benzotriazole and 5-methylbenzotriazole in recycled water recharged into an anaerobic aquifer: Column studies. Water Res. 2015, 70, 184-195. [CrossRef] [PubMed]

43. Maurer, M.; Escher, B.I.; Richle, P.; Schaffner, C.; Alder, A.C. Elimination of beta-blockers in sewage treatment plants. Water Res. 2007, 41, 1614-1622. [CrossRef] [PubMed] 
44. Maeng, S.K.; Sharma, S.K.; Lekkerkerker-Teunissen, K.; Amy, G.L. Occurrence and fate of bulk organic matter and pharmaceutically active compounds in managed aquifer recharge: A review. Water Res. 2011, 45, 3015-3033. [CrossRef] [PubMed]

45. Nödler, K.; Hillebrand, O.; Idzik, K.; Strathmann, M.; Schiperski, F.; Zirlewagen, J.; Licha, T. Occurrence and fate of the angiotensin II receptor antagonist transformation product valsartan acid in the water cycle-A comparative study with selected beta-blockers and the persistent anthropogenic wastewater indicators carbamazepine and acesulfame. Water Res. 2013, 47, 6650-6659. [CrossRef] [PubMed]

46. Hübner, U.; Miehe, U.; Jekel, M. Optimized removal of dissolved organic carbon and trace organic contaminants during combined ozonation and artificial groundwater recharge. Water Res. 2012, 46, 6059-6068. [CrossRef] [PubMed]

47. Onesios, K.M.; Bouwer, E.J. Biological removal of pharmaceuticals and personal care products during laboratory soil aquifer treatment simulation with different primary substrate concentrations. Water Res. 2012, 46, 2365-2375. [CrossRef] [PubMed]

48. Lester, Y.; Mamane, H.; Zucker, I.; Avisar, D. Treating wastewater from a pharmaceutical formulation facility by biological process and ozone. Water Res. 2013, 47, 4349-4356. [CrossRef] [PubMed]

49. Iobbi-Nivol, C.; Pommier, J.; Simala-Grant, J.; Méjean, V.; Giordano, G. High substrate specificity and induction characteristics of trimethylamine-N-oxide reductase of Escherichia coli. Biochim. Biophys. Acta (BBA) Protein Struct. Mol. Enzymol. 1996, 1294, 77-82. [CrossRef]

50. Maeda, S.; Uchida, S.; Kisaki, T. Microbial Degradation of Nicotine-N'-oxide I Degradation Products. Agric. Biol. Chem. 2014, 42, 1455-1460.

51. Buffle, M.-O.; von Gunten, U. Phenols and Amine Induced HO. Generation during the Initial Phase of Natural Water Ozonation. Environ. Sci. Technol. 2006, 40, 3057-3063. [CrossRef] [PubMed]

52. Von Gunten, U. Ozonation of drinking water: Part I. Oxidation kinetics and product formation. Water Res. 2003, 37, 1443-1467. [CrossRef]

53. Real, F.J.; Benitez, F.J.; Acero, J.L.; Sagasti, J.J.P.; Casas, F. Kinetics of the Chemical Oxidation of the Pharmaceuticals Primidone, Ketoprofen, and Diatrizoate in Ultrapure and Natural Waters. Ind. Eng. Chem. Res. 2009, 48, 3380-3388. [CrossRef]

54. Hübner, U.; von Gunten, U.; Jekel, M. Evaluation of the persistence of transformation products from ozonation of trace organic compounds-A critical review. Water Res. 2015, 68, 150-170. [CrossRef] [PubMed]

55. Letzel, T.; Bayer, A.; Schulz, W.; Heermann, A.; Lucke, T.; Greco, G.; Grosse, S.; Schüssler, W.; Sengl, M.; Letzel, M. LC-MS screening techniques for wastewater analysis and analytical data handling strategies: Sartans and their transformation products as an example. Chemosphere 2015, 137, 198-206. [CrossRef] [PubMed]

(C) 2017 by the authors. Licensee MDPI, Basel, Switzerland. This article is an open access article distributed under the terms and conditions of the Creative Commons Attribution (CC BY) license (http:/ / creativecommons.org/licenses/by/4.0/). 